\title{
La música popular Popular music
}

¿P or qué tenemos música? Preguntó una vez Ingmar Bergman a un famoso director de orquesta contemporáneo; éste se quedó pensativo y al cabo de un rato respondió: la verdad es que no lo sé.

En todas las épocas y culturas ha existido la fascinación por los sonidos; sin embargo, durante mucho tiempo sólo las élites pudieron acceder a la audición musical elaborada. No cualquiera podía tener a su disposición una pequeña orquesta para su deleite.

Probablemente fue la producción masiva de instrumentos musicales, junto con el desarrollo de las salas de espectáculo lo que permitió el acceso de mayores grupos sociales al disfrute de la música. Posteriormente, el gramófono y la radio lograron masificar definitivamente la música de gusto popular.

A diferencia de la música de academia o de conservatorio y la música étnica, tradicional o folclórica, la llamada música popular no corresponde propiamente a un género ni a un estilo, sino más bien se nutre de muchos y muy variados, traspasa fronteras y tiempos, se adapta sin prejuicios a los adelantos técnicos y a los cambios estéticos, y por sobre todo, gusta.

Una vertiente de ella surge en Europa en el siglo diecinueve para un público aburrido de la grandiosidad de la ópera, que en Wagner puede

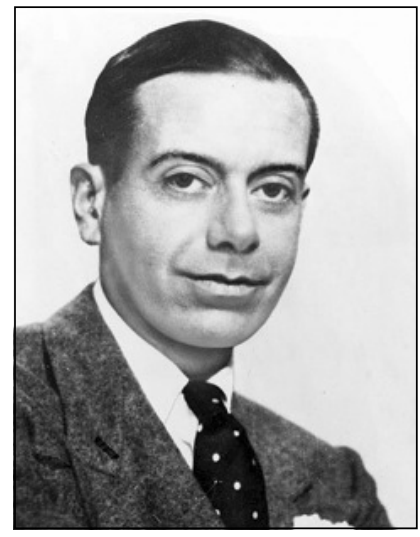

Figura 1. Cole Porter, compositor popular norteamerica-

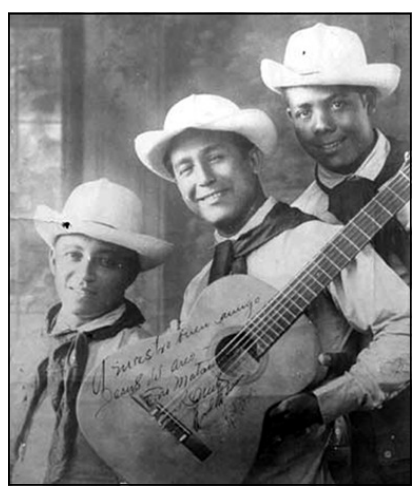
no.

Figura 2. Trío Matamoros, conjunto fundacional del son cubano.
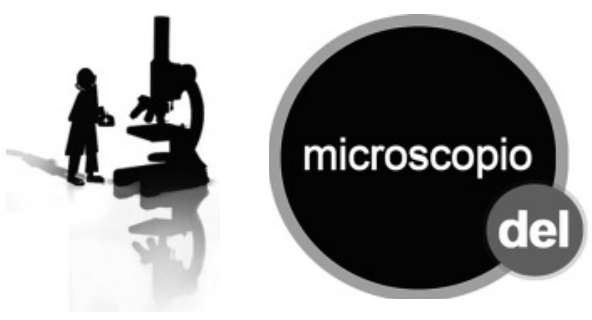

significar estar seis horas sentado. Es la opereta, género que produjo piezas maestras del gusto popular, como "El murciélago" y "El barón gitano" de Strauss, "Caballería ligera" de Von Suppe (todos la hemos tarareado), "La viuda alegre" de Lehar y muchas más.

Hacia los años veinte, la opereta cruza el Atlántico para dar forma a la comedia musical, a la que dedicaron piezas compositores como Leonard Bernstein y George Gershwin. Numerosas canciones de comedias musicales fueron convertidas en éxito por cantantes populares norteamericanos, especialmente las compuestas por Irving Berlin y Cole Porter. Obras notables del género fueron "West Side Story" de 1957, "Los miserables" de 1987, y las obras de Andrew Lloyd Weber, nacido en Inglaterra en 1948, que a los 23 años de edad sorprendió al mundo con "Jesucristo Superstar" y luego con "Evita", "Cats", y "El fantasma de la ópera".

Por otro lado, la variedad de músicas populares de América Latina y el Caribe semeja las ramas de un frondoso árbol, con un tronco común y muchas relaciones entre sí. Ya desde la conquista se inició un proceso de criollización, donde contradanzas, cuadrillas, y polcas, además de óperas, cánticos, marchas y canciones marineras se fusionaron con los ritmos africanos y de los pueblos originarios creando una música característica, con polos locales bastante definidos. Surgen el candombe y el tango en el Río de La Plata, el samba en Brasil, y en otros rincones la marinera, la chacarera, el pasillo, el joropo; la lista es interminable repartida por toda América, con la peculiaridad que la canción y la danza son indisolubles debido a la influencia africana.

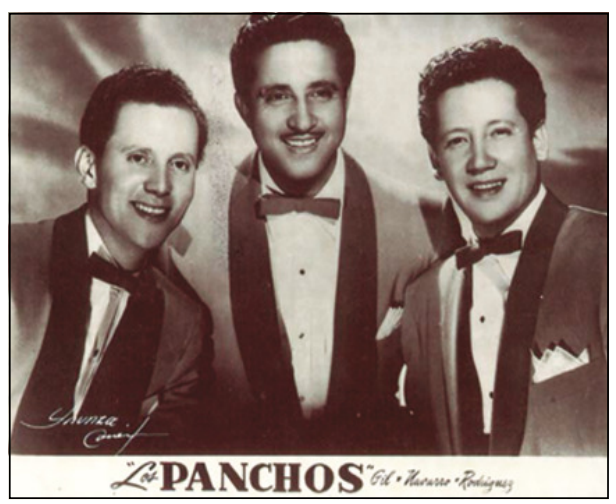

Figura 3. Los Panchos, conjunto principal de la época del bolero.

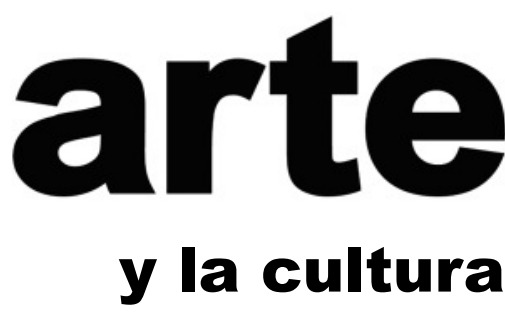

En el Caribe, Cuba surge como el crisol de culturas en lo que a música popular se refiere; se manifiestan influencias españolas en la guajira y la habanera y francesas en el danzón. Para 1930 se consolida el son como la forma musical que será la fuente de inspiración de la llamada música latina en los años posteriores.

Entonces se produce un hecho inevitable: la música cubana y la música norteamericana se encuentran hacia 1950, especialmente en Nueva York donde se produce la fusión entre las formas caribeñas, la rumba y la conga primero, y luego el mambo, y el chachachá con el jazz. Las duplas de Charlie Parker con Frank Grillo (Machito) y especialmente Dizzy Gillespie con el conguero Chano Pozo, remecen profundamente la escena de la música. Posteriormente otros intérpretes populares como Celia Cruz, Ernesto Puente y Rubén Blades, desarrollaron una forma contemporánea del son: la salsa.

La otra gran vertiente del crisol cubano se dirigió a Méjico donde floreció el bolero, con numerosos tríos melódicos y acompañamiento de guitarras. El bolero fue la forma musical que dominó la escena popular durante tres décadas desde 1935, fecha de la muerte de Carlos Gardel y de la decadencia del tango, hasta 1965 en que se produce la consolidación definitiva del rock and roll y el rock en el gusto popular latinoamericano; sin embargo la balada romántica, continuadora del bolero, persiste como forma musical popular hasta nuestros días.

La música popular, al igual que el fútbol o el baile, forma parte de la cultura de los pueblos, y seguirá acompañándonos como lo ha venido haciendo hasta hoy, aunque su aparente simplicidad y gusto masivo no le otorguen nunca un lugar entre las llamadas bellas artes.

\section{Referencias}

1.- González J P, Ohlsen O, Rolle C. Historia social de la música popular en Chile, 1950-1970. Ediciones U.C. Santiago, 2009.

2.- Leymarie I. La música latinoamericana. Ediciones B. Barcelona 1997.

Ernesto Payá G. Servicio de Pediatría Hospital de Carabineros, Santiago 